\title{
Aberrant Glycosylation as Biomarker for Cancer: Focus on CD43
}

\author{
Franca Maria Tuccillo, ${ }^{1}$ Annamaria de Laurentiis, ${ }^{2}$ Camillo Palmieri, ${ }^{2}$ \\ Giuseppe Fiume, ${ }^{2}$ Patrizia Bonelli, ${ }^{1}$ Antonella Borrelli, ${ }^{1}$ Pierfrancesco Tassone, ${ }^{2}$ \\ Iris Scala, ${ }^{3}$ Franco Maria Buonaguro, ${ }^{1}$ Ileana Quinto, ${ }^{2}$ and Giuseppe Scala ${ }^{2}$ \\ ${ }^{1}$ Molecular Biology and Viral Oncogenesis Unit, Department of Experimental Oncology, Istituto Nazionale Tumori \\ "Fondazione G. Pascale"-IRCCS, Naples, Italy \\ ${ }^{2}$ Department of Experimental and Clinical Medicine, University "Magna Graecia" of Catanzaro, Catanzaro, Italy \\ ${ }^{3}$ Department of Pediatrics, University of Naples "Federico II", Naples, Italy
}

Correspondence should be addressed to Franca Maria Tuccillo; f.tuccillo@istitutotumori.na.it and Ileana Quinto; quinto@unicz.it

Received 27 September 2013; Accepted 10 December 2013; Published 13 February 2014

Academic Editor: Renato Franco

Copyright (C) 2014 Franca Maria Tuccillo et al. This is an open access article distributed under the Creative Commons Attribution License, which permits unrestricted use, distribution, and reproduction in any medium, provided the original work is properly cited.

\begin{abstract}
Glycosylation is a posttranslational modification of proteins playing a major role in cell signalling, immune recognition, and cell-cell interaction because of their glycan branches conferring structure variability and binding specificity to lectin ligands. Aberrant expression of glycan structures as well as occurrence of truncated structures, precursors, or novel structures of glycan may affect ligand-receptor interactions and thus interfere with regulation of cell adhesion, migration, and proliferation. Indeed, aberrant glycosylation represents a hallmark of cancer, reflecting cancer-specific changes in glycan biosynthesis pathways such as the altered expression of glycosyltransferases and glycosidases. Most studies have been carried out to identify changes in serum glycan structures. In most cancers, fucosylation and sialylation are significantly modified. Thus, aberrations in glycan structures can be used as targets to improve existing serum cancer biomarkers. The ability to distinguish differences in the glycosylation of proteins between cancer and control patients emphasizes glycobiology as a promising field for potential biomarker identification. In this review, we discuss the aberrant protein glycosylation associated with human cancer and the identification of protein glycoforms as cancer biomarkers. In particular, we will focus on the aberrant CD43 glycosylation as cancer biomarker and the potential to exploit the UN1 monoclonal antibody (UN1 mAb) to identify aberrant CD43 glycoforms.
\end{abstract}

\section{Introduction}

Protein glycosylation is the most common and complex posttranslational modification involved in many physiological events, including protein folding and trafficking, cell-cell and cell-matrix interactions, cellular differentiations and the immune response [1-5]. Approximately, $1 \%$ of human genes are required for this specific process [6] with more than $50 \%$ of proteins being glycosylated according to SwissProt database [7]. In humans, protein-linked glycans can be divided into two main types: $\mathrm{N}$-linked (linkage to the amide group of asparagine residues in the consensus sequence Asn$\mathrm{X}$-Ser/Thr) (Figure 1) and O-linked (linkage to the hydroxyl group of serine, threonine, or hydroxylysine) (Figures 2(a)2(d)). Carbohydrate additions to proteins occur during or after translation as the nascent proteins transit through the endoplasmic reticulum (ER) and subsequent organelles in the secretory pathway of the cell. Glycosylation is not a templatebased process such as DNA, RNA, or protein synthesis but is rather based on the balance achieved by the expression and activity levels of the different enzymes involved in the glycosylation process, such as glycosyltransferases and glycosidases, and on the availability of precursor monosaccharide molecules, which in turn depends on the availability of nutrient resources and expression of enzymes responsible for their synthesis and interconversion $[3,4,7,8]$. This highly increases the complexity of the protein glycosylation process and the molecular microheterogeneity of glycoproteins [9]. Glycans exist as membrane-bound glycoconjugates or as secreted molecules, which can become integral parts of the extracellular matrix. In these locations, glycans can mediate cell adhesion and motility as well as intracellular signalling 


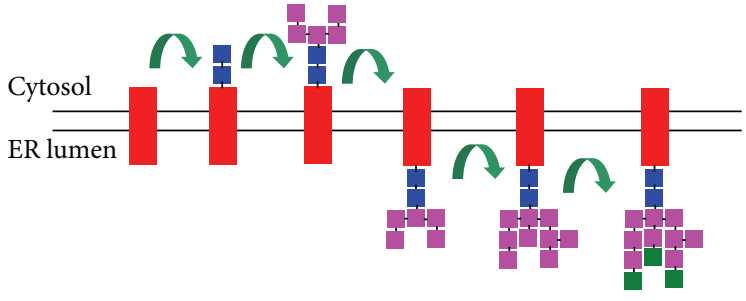

(a)

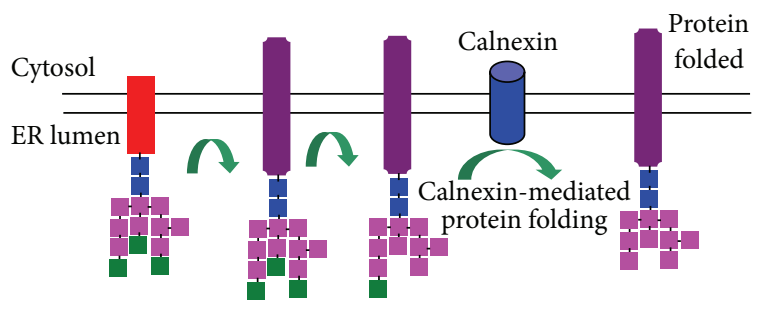

(b)

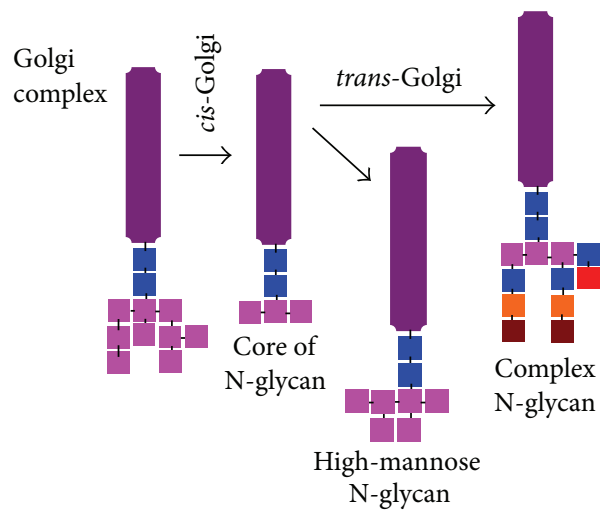

(c)

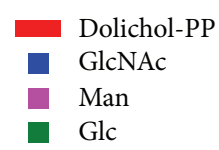

$$
\begin{aligned}
& \text { Gal } \\
& \text { Sialic acid } \\
& \text { Fucose } \\
& \text { Target protein } \\
& \text { Asn-X-Ser/Thr }
\end{aligned}
$$

(d)

FIGURE 1: Schematic representation of N-glycosylation process. N-Glycosylation is an evolutionary conserved stepwise process that can be summarized as follows. (a) The assembling of the precursor oligosaccharide occurs at the cytoplasmic side of endoplasmic reticulum (ER) and starts with dolichol-pyrophosphate (Dol-PP), which is a nucleotide linked to a monosaccharide on a lipid carrier, an isoprenoid compound (90-100 carbon atoms total). The sequential incorporation of monosaccharides N-acetyl-glucosamine (GlcNAc) and Mannose (Man) is catalyzed by various glycosyltransferases. Once the intermediate Dol-PP-GlcNA $\mathrm{CMan}_{5}$ is made, it flips to the luminal side of the $\mathrm{ER}$, where four further residues of mannose and three residues of glucose (Glc) are added, leading to Dol-PP-GlcNAc $\mathrm{Man}_{9} \mathrm{Glc}_{3}$. (b) When the proteins containing the consensus sequence for N-glycosylation (Asn-X-Ser and Asn-X-Thr) translocate to the ER, they are glycosylated by the oligosaccharyltransferase (OST) that catalyzes the transfer of the $\mathrm{N}$-glycan to specific asparagine residues included within the consensus sequence (Asn-X-Ser/Thr) of the target proteins. After the oligosaccharide is transferred to the target protein, specific enzymes remove the three Glucose residues and one particular Mannose. The ER lumen contains a specific glycosyltransferase that binds to target protein, catalyzing the addition of Glucose residues only when the target protein is unfolded or misfolded. The newly glycosylated Glc $\mathrm{GlcNAc}_{2} \mathrm{Man}_{7-9}$ oligosaccharides are then bound by two specific lectins, the ER-membrane-attached Calnexin or ER-luminal Calreticulin, which will allow the glycoprotein folding. Once folding is completed, the glucose residue is removed. (c) N-Glycosylated proteins move from ER to Golgi, where specific enzymes catalyse their sequential modifications to the $\operatorname{Man}_{8}(\mathrm{GlcNAc})_{2}$ chains. In particular, in the cis-Golgi compartment, most Mannose residues of the original backbone chain are removed, leading to a N-glycan core structure constituted by GlcNAc $_{2} \mathrm{Man}_{3}$. In mammals, two main groups of oligosaccharides linked to proteins are found: complex N-glycans and high-Mannose N-glycans. These structures are generated during the passage of the proteins toward the trans-side by the subsequent addition of Mannose residues (for the high-mannose $\mathrm{N}$-glycans) and by addition of three residues of $\mathrm{N}$-acetyl glucosamine (GlcNAc), two residues of Gal (galactose), two residues of NeuAc (N-acetylneuraminic acid) or sialic acid, and a single fucose residue (for the complex N-glycans). (d) Graphic legend of described structures.

events [10]. Moreover, changes in glycan structures are associated with many physiological and pathological events such as cell growth, migration, and differentiation. Consequently, aberrant glycosylation occurring in cancer cells may influence cell proliferation, adhesion, and motility, as well as angiogenesis and metastasis [11, 12]. Neoplastic transformation is frequently associated with the expression of oncofetal antigens, which are usually expressed in fetal tissues and cancer tissues and not in normal adult tissues. These antigens are primarily glycoproteins and their glycan epitopes were identified by the first "tumour-specific" monoclonal antibodies [12]. Interest in these changes increased when a significant correlation between certain types of altered glycosylation and prognosis was observed. Glycan alterations in tumours, such as underexpression, truncation, or modified branching patterns, may correlate with cell growth and enhanced 
Normal O-glycan structures

Core-1 structure

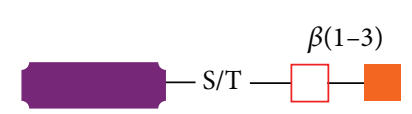

(a)

Core-2 structure

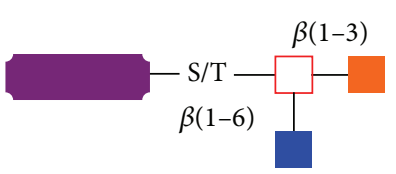

(b)

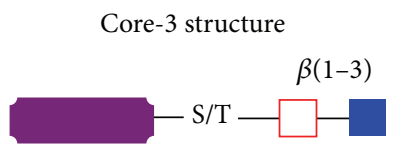

(c)

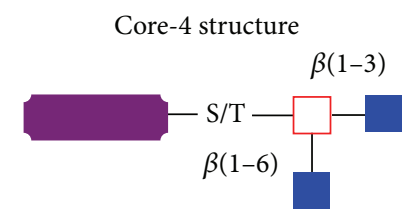

(d)
Premature sialylation

cancer-associated $O$-glycan structures

Sialyl T-antigen

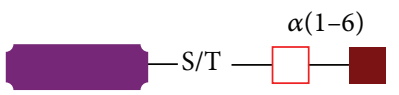

(e)

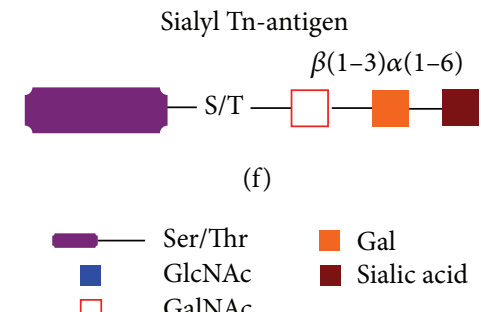

(g)

FIgURE 2: Mucin-type $O$-glycosylation. Different forms of $O$-glycosylation of proteins occur in animals. Mucin-type $O$-glycosylation is the most abundant form of protein $\mathrm{O}$-glycosylation and consists of glycans attached via $\mathrm{O}$-linked $\mathrm{N}$-acetylgalactosamine (GalNAc) to serine and threonine residues. Other types of $O$-glycosylation include mannose-, galactose- (added to a residue of hydroxylysine), fucose-, glucose-, xylose-, and $\mathrm{N}$-acetylglucosamine-O-glycosylation. GalNAc-O-glycosylation originates in the Golgi apparatus after protein folding, while other types of $\mathrm{O}$-glycosylation of proteins in the secretory pathway initiate in the ER. Mucin-type $O$-glycosylation is initiated by a large family of homologous proteins, named N-acetylgalactosamine (GalNAc)-transferase that catalyses the transfer of GalNAc from UDP-GalNAc to Ser or Thr residues of target glycoprotein. These enzymes are sequentially and functionally conserved across species and their expression is time and tissue specific, suggesting a very complex regulation. Up to 20 different isoforms of polypeptide $\mathrm{N}$-acetyl- $\alpha$ - $\mathrm{D}$-galactosaminyltransferases are known and many are specific for the sites of attachment of the GalNAc to serine/threonine residues, influencing the density and the specific position of the $\mathrm{O}$-glycosylation of target proteins. Thereafter, specific glycosyltransferases can catalyse the addition to GalNAc of specific monosaccharides generating four common subtypes (Core-1-, Core-2-, Core-3-, and Core-4-O-glycan structures) based on differential monosaccharide linkage reactions to the GalNAc (GalNAc $\alpha$-Ser/Thr). Most $O$-glycans contain the Core-1 subtype (a), which is generated by the addition of galactose to the GalNAc through a $\beta 1-3$ linkage by the Core-1-( $\beta 1-3)$ galactosyltransferase. This structure is usually further extended by the addition of monosaccharides such as $\mathrm{N}$-acetylglucosamine, galactose, $\mathrm{N}$-acetylneuraminic acid, and fucose. (b) Core-2$O$-glycans are generated by the addition of GlcNAc to the GalNAc through a $\beta 1-6$ linkage. In order to generate Core-2-O-glycans, Core-1 structure is required as a substrate; thus, the Core- 2 structure includes the Core- 1 structure. The Core-2-O-glycan can be further extended into either a mono- or biantennary form by addition of multiple galactose (Gal $(\beta 1-4)$ GlcNAc) units and terminal linkages of fucose and sialic acid. (c) Core-3 subtype is generated by the addition of GlcNAc in a $\beta 1-3$ linkage to the GalNAc, and it can be extended by the addition of GlcNAc in a $\beta 1-6$ linkage, generating the Core-4-O-glycan (d), which also can be extended by addition of monosaccharides, such as galactose, fucose, and sialic acid, which results in the synthesis of a wide spectrum of $O$-glycan structures. In some cases, the biosynthesis of $O$-glycans is stopped by the addition of sialic acid residues in early biosynthesis leading to "dead ends" of $O$-glycan structures that cannot be further modified ((e), (f)). Truncated $O$-glycan structures are frequently found in cancer cells as tumour antigens, suggesting that aberrant glycosylation may contribute to cancer progression by modifying cell signalling, adhesion, and antigenicity. (g) Graphic legend of described structures.

proliferative capacity of tumour cells. Of interest, despite the wide diversity of glycan structures, only a few distinct glycan changes are associated with malignant transformation and tumour progression. This suggests that specific glycosylation patterns correlate with tumour progression, likely due to gain of function in cell fitness and survival [12]. Altered patterns of protein glycosylation in transformed cells were initially exploited using plant lectins based on their specific binding to distinct sugar sequences [13]. In animals, lectins are involved in different biological functions, such as quality control of secreted proteins, cell-cell recognition, cell adhesion and motility, and pathogen-host recognition. Several lectins are found on the surface of immune cells and endothelial cells of blood vessels and act as extracellular matrix proteins and soluble adhesion molecules including mannose-binding proteins or galactose-binding lectins (galectins). The interactions of lectins with tumour cell glycans can promote tumour progression. 
TABLE 1: Cancer-associated glycan alterations observed in the referred studies.

\begin{tabular}{|c|c|c|}
\hline Structure & Findings & References \\
\hline $\mathrm{T}$ antigen & Overexpression & [14-16] \\
\hline Sialyl-T antigen & Overexpression & {$[12,14]$} \\
\hline Tn antigen & Overexpression & {$[17-20]$} \\
\hline Sialyl-Tn antigen & Overexpression & {$[17,18,20-22]$} \\
\hline Sialyl-Lewis ${ }^{\mathrm{a}}$ & Overexpression & [23-27] \\
\hline Sialyl-Lewis ${ }^{\mathrm{x}}$ & Overexpression & {$[28-30]$} \\
\hline Core-2 & Overexpression/underexpression & {$[12,31]$} \\
\hline Core-3 & Underexpression & {$[12,31]$} \\
\hline Core- 4 & Underexpression & {$[12,31]$} \\
\hline $\begin{array}{l}\beta 1-6 \text { branching of } \\
N \text {-glycans }\end{array}$ & Overexpression & {$[32,33]$} \\
\hline Fucosylation & Overexpression & [34-37] \\
\hline Sialylation & Overexpression & {$[38,39]$} \\
\hline
\end{tabular}

\section{Altered Glycosylation Patterns in Cancer}

Aberrant protein glycosylation is a well-established event in oncogenesis (Table 1) and cancer progression [40-42]. Mucin-type $O$-glycosylation, consisting of glycans attachment via $O$-linked $\mathrm{N}$-acetylgalactosamine (GalNAc) to serine and threonine residues, is one of the most abundant forms of protein glycosylation in animals. Mucins (MUC) are large glycoproteins with a "rod-like" conformation that harbour many clustered glycosylated serines and threonines in tandem repeat structures (PTS domain). Fifty to ninety percent of the mucin molecule by weight consists of O-linked oligosaccharides (O-glycans). The $\mathrm{O}$-glycan cores are usually lengthened and modified by addition of diverse sugars and sulphate esters, thus generating different structural conformations. Human MUC family includes 21 different members named from MUC1 to MUC21. Members of the mucin family are classified as secreted mucins (when released in the intercellular space) and transmembrane mucins (when expressed on the cellular surface). Secreted mucins constitute a protective barrier over the epithelium. O-Glycans of cell surfacebound mucins modulate the interactions with the environment through binding to lectins and antigens. Depending on the structures of $O$-glycan chains, mucins can have pro- or antiadhesive properties. Transmembrane mucins consist of a glycosylated extracellular domain, a hydrophobic transmembrane region, and a cytoplasmic tail. They contribute to the physical barrier and interact with cytoskeletal adaptor proteins and signalling molecules, thus contributing to cell adhesion and signalling pathways. Overexpression of mucins in carcinomas has been described for many years [31, 43-46]. In the normal polarized epithelium, mucins are expressed exclusively on the apical border of the cell sheets, toward the lumen of a hollow organ, and soluble mucins are secreted exclusively into the lumen. Malignant epithelial cells lose the correct polarity of mucins as they are expressed on the entire cellular membrane and secreted mucins can enter the extracellular space and body fluids, such as the blood [12, 44]. Mucins expressed in carcinoma cells from epithelia and in malignant haematopoietic cells are the ones exhibiting the most altered glycosylation pattern. Aberrant glycan structures can modify antigenic and adhesive properties of cancer cells and their potential to migrate. In addition to interfering with the specific binding to endogenous lectins, the elongated carbohydrate structures and the negative charge of mucins can sterically hinder the interaction of other adhesion molecules, such as cadherins and integrins, and their natural ligands, thus facilitating the detachment of tumour cells from the primary tumour during the process of metastasis. Moreover, mucins can physically hamper the interactions with the host immune cells, such as natural killer cells, and mask the presentation of antigenic peptides by the major histocompatibility complex [47].

Incomplete glycosylation is another abnormal feature of mucins found in human cancer. The expression of truncated $O$-glycans $\mathrm{Tn}$, sialyl-Tn, and T antigens was reported in different human tumours [14-19, 21, 48] (Figures 2(e) and 2(f)). Since these structures are not expressed in normal tissues, they can cause immune responses in the patients. In fact, the expression of the T (Gal $\beta 1-3$ GalNAc- $\alpha 1-O-S e r / T h r)$ and $\mathrm{Tn}$ (GalNAc- $\alpha 1-O-S e r / T h r)$ antigens in carcinomas correlated with the presence of antibodies directed against these antigens and the prognosis of the disease [12, 15, 17]. Further, incomplete glycosylation leads to the expression of "naked" mucin polypeptides [44-46]. The aberrant expression of truncated $O$-glycans on cancer cells can be due to defects in the secretory pathway organelles (ER and Golgi) and to altered glycosyltransferase expression. These alterations can also depend on mutations in cosmc (Core- $1 \beta 3$-Gal-T-specific molecular chaperone), a chaperone required for glycosyltransferase function $[17,20]$. Expression of truncated $O$-glycans may also be due to the absence of glycosyltransferases responsible for the synthesis of core structures used as substrates for chain elongation [22], or overexpression of sialyltransferases responsible for the synthesis of sialyl-Tn and sialyl-T antigens $[17,49,50]$.

Deregulated N-glycosylation of proteins has been observed in different pathologies and most biomarkers used for diagnosis, prognosis, and prediction of many cancers are N-linked glycosylated proteins [51, 52]. Several N-glycoproteins differentially expressed in some cancerous diseases have been reported, including the following: (1) upregulation of alpha-1-antichymotrypsin in both non-small-cell lung carcinoma (NSCLC) and hepatocellular carcinoma (HCC) $[53,54]$, (2) upregulation of galectin-3-binding protein (Gal3BP or Mac-2 BP) in both HCC and ovarian cancer [55, 56], (3) downregulation of insulin-like growth factor binding protein 3 in HCC and NSCLC $[54,56]$, and (4) increased expression of periostin in aggressive prostate cancer [57] and most ovarian cancer subtypes [55]. Altered branching of $\mathrm{N}$-glycans is also involved in many neoplastic diseases. As the branching of $\mathrm{N}$-glycans is involved in various biological functions, such as signal transduction, cell adhesion, cell motility, and cell proliferation, it is reasonable that the altered activity of distinct glycosyltransferases may be involved in various cancerous processes, including cancer cell migration, invasion, and metastasis [58]. In particular, 
some glycosyltransferases, including $\mathrm{N}$-acetylglucosaminyltransferase III (GnT-III), N-acetylglucosaminyltransferase $\mathrm{V}$ (GnT-V), and $\alpha$-1, 6-fucosyltransferase (Fut8), are strongly associated with many types of cancer. GnT-III catalyses the addition of GlcNAc to mannose linked to an underlying $\mathrm{N}$-acetylglucosamine through a $\beta$-1, 4 linking, producing a "bisecting" GlcNAc linkage. The introduction of bisecting GlcNAc catalysed by GnT-III suppresses additional processing and elongation of $\mathrm{N}$-glycans that are catalysed by other enzymes, such as GnT-IV, GnT-V, and GnT-VI [59]. GnT-III suppressed the lung metastatic foci in mice injected with GnT-III-transfected melanoma B16 cells as compared to mice treated with mock-transfected cells [60]; the mechanism of suppression of metastatic foci has been referred to the branching modifications of essential glycoproteins, such as epithelial growth factor receptor (EGFR), and adhesion molecules including integrin and cadherin [6163]. On the contrary, GnT-V, which catalyses the formation of $\beta-1,6$-GlcNAc branching structures, plays pivotal roles in the development of tumour cell invasiveness and metastasis. In particular, the increase in $\beta-1,6$ branching of $\mathrm{N}$-glycans depending on upregulated GnT-V activity was found to be associated with cancer growth and metastasis $[32,33,64,65]$. Fut8 catalyses the transfer of the fucose residue from fucoseGDP to the innermost GlcNAc residue of hybrid and complex $\mathrm{N}$-linked oligosaccharides in the specific position 6 of glycoproteins, resulting in core fucosylation through an $\alpha-1,6$ linking. Core-fucosylated glycoproteins are widely distributed in mammalian tissues and may be altered under pathological conditions, such as hepatocellular carcinoma and liver cirrhosis $[34,35]$. Notably, the increase in Fut8 expression and activity was observed in thyroid papillary carcinomas and correlated to tumour size and lymph node metastasis, and thus Fut8 expression represents a biomarker of progression of thyroid papillary carcinomas [36].

\section{Glycan-Based Serological Assays in Cancer}

Aberrant glycosylation of membrane-bound or secreted glycans associated with neoplastic transformation has become cancer biomarkers. Serological assays are currently used in clinical practice to detect and quantify glycans in the serum of cancer patients. The measurement of circulating glycoconjugates is used for (a) diagnosis, (b) monitoring of clinical course under therapy, (c) detection of early disease recurrence, and (d) prognosis. Serum levels of glycoconjugates, such as SLe ${ }^{\mathrm{a}}$ (CA19-9), STn (CA72-4), and the mucin glycoproteins MUC1 (CA15-3) and MUC16 (CA125) [66-69], are usually measured. These biomarkers cannot be used for cancer screening as they are broadly expressed by various types of cancer [70-72] and can also be produced in some nonneoplastic and inflammatory diseases [73], thus reducing the specificity required for screening [74]. Nevertheless CA125, for instance, remains the best available biomarker of ovarian cancer. CA125 is a transmembrane mucin that is released into the extracellular space by enzymatic cleavage. Elevated levels of CA125 are found in the serum of 50\% of patients with stage I ovarian cancer and in about $25 \%$ of serum samples collected within 60 months preceding diagnosis of ovarian cancer [75]. Moreover, high serum levels of CA125 are detected in $80 \%$ of patients with epithelial ovarian cancer $[67,76]$. In addition, the CA125 levels are directly correlated with the progression or regression of the disease, and the preoperative levels of CA125 are used to assess the prognosis of ovarian cancer patients. On the whole, CA125 is a valuable serum tumour marker for monitoring response to chemotherapy, detecting disease recurrence, and evaluating prognosis [77-79].

MUC1 is a transmembrane mucin overexpressed and aberrantly glycosylated in more than $90 \%$ of human breast cancer. As a consequence of neoplastic transformation and loss of epithelial cell polarity, MUC1 molecules enter the bloodstream. Circulating MUC1 levels are measured by CA15-3 assay. Clinical utility of CA15-3 is in monitoring the response to therapy, in detecting early disease recurrence, and in assessing prognosis of patients with breast cancer [80-83]. Elevated preoperative levels of CA15-3 are associated with poor prognosis. Moreover, even in the absence of measurable disease, increasing levels of CA15-3 indicate a treatment failure [74, 83]. Clinical utility of this marker in other cancers is still under investigation.

CA19-9 assay detects aberrant sialyl Lewis ${ }^{a}$ glycan $\left(\right.$ SLe $\left.^{\text {a }}\right)$ that is expressed on glycolipids and glycoprotein in patients with gastrointestinal malignancies. This marker is useful to monitor clinical response to therapy and to evaluate the prognosis of patients with pancreatic, colorectal, gastric, or biliary cancer. CA19-9 is neither tumour specific nor organ specific but has the highest sensitivity and specificity for pancreatic cancer. Levels of this marker strictly correlate with the clinical response to treatment and can predict the recurrence of tumour after pancreatectomy prior to clinical or instrumental evidence of disease [23, 24]. In colon cancer, patients with higher levels of CA19-9 have in the first three years after diagnosis a mortality rate four times higher than those with lower levels. In gastric cancer, CA19-9 levels before surgery are a prognostic marker and an independent risk factor for the relapse of gastric carcinoma [25-27, 84].

CA72-4 assay is used to detect aberrant sialyl-Tn (STn), a carbohydrate antigen expressed in mucins. Elevated levels of this antigen are detected in serum of patients with various epithelial cancers, such as gastric, colorectal, pancreatic, lung, and breast carcinomas, and are usually associated with poor prognosis, tumour metastasis, and a decreased survival [15$17,21,22,26,48,85,86]$. CA72- 4 assay is used for monitoring gastric carcinoma, given that a relevant serological level increase is considered a predictor of tumour recurrence [26]. Moreover, CA72-4 is an independent prognostic factor in gastric carcinoma and in pancreatic cancer $[87,88]$.

An additional serological assay measures the serum levels of carcinoembryonic antigen (CEA), a member of a family of N-glycoproteins, that is overexpressed in a wide range of human carcinomas, including colorectal, gastric, pancreatic, lung, and breast carcinomas, and is shed into circulation [25, 27, 80, 82, 83, 89-93]. However, moderate to significant increase in serum CEA levels is observed in a variety of chronic and acute inflammatory diseases that are unrelated to cancer, including alcoholic cirrhosis, cholelithiasis, obstructive jaundice, cholangitis, liver abscess, 
emphysema, bronchitis, gastric ulcer, gastritis, diverticulitis, diabetes, and collagen vascular diseases $[88,94]$. Thus, even though the serum CEA level is measured in patients with colorectal cancer for prognosis and clinical follow-up of patients $[95,96]$, it cannot be used for screening because of its low sensitivity in early stages of colorectal cancer.

Improved specificity and diagnostic capability can be achieved by developing assays that detect cancer-specific alterations of glycoprotein glycosylation. This is the case of alpha-fetoprotein (AFP), a marker of HCC. AFP is not HCC specific because elevated serum levels of AFP are also found in other conditions such as pregnancy, hepatitis, and liver cirrhosis. Total AFP can be separated into three glycoforms; of those the AFP-L3 glycoform, consisting of core-fucosylated AFP, has been shown to be highly specific for HCC even at early stage of disease and useful for early tumor recognition [37].

\section{CD43 Is a Mucin-Type Cancer-Associated Glycoprotein}

CD43, also named leukosialin, sialophorin, galactoglycoprotein, leukocyte sialoglycoprotein, and is a mucin-like type I transmembrane protein. In humans, it is expressed in haematopoietic cells, including $\mathrm{T}$ lymphocytes, monocytes, granulocytes, natural killer cells, platelets, and haematopoietic stem cells, with the exception of mature erythrocytes and B cell subpopulations [97-103].

The human CD43 protein is encoded by a single gene on chromosome 16 (gene map locus 16p11.2) and comprises the signal peptide of 19 amino acids at the amino terminus followed by a highly glycosylated extracellular region of 235 amino acids, the transmembrane region of 23 amino acids, and the intracellular carboxy-terminal region of 123 amino acids $[104,105]$. The mucin-like extracellular domain has an extended rod-like structure that protrudes about $45 \mathrm{~nm}$ from the cell surface and is serine and threonine rich, thus enabling an extensive $O$-glycosylation (about 80 $O$-linked glycan chains). Only one potential N-glycosylation site is located near to the transmembrane domain at position N239 [106, 107]. The intracellular region contains a number of potential phosphorylation sites that can mediate transduction of activation signals. The unglycosylated form of CD43 migrates on SDS-PAGE with a molecular weight of $54 \mathrm{kDa}$ [97], whereas CD43 from different haematopoietic cell lines displays increased molecular weights since it is glycosylated with $O$-linked chains that differ in core structure and sialylation [101, 108, 109]. Two CD43 glycoforms have been described in haematopoietic cells depending on cell type and cellular activation. Resting T lymphocytes express mostly leukosialin with an apparent molecular weight of $115 \mathrm{kDa}$, which contains almost exclusively tetrasaccharides, while activated T cells, monocytes, neutrophils, and platelets express a glycoform with the apparent molecular weight of $130 \mathrm{kDa}$, which possesses mainly branched hexasaccharides $[97,98,110]$. CD43 glycoforms can be coexpressed on the surface of the same cell [111] suggesting that they are functionally distinct. CD43 has a negative net charge due to the high content of sialic acid in the $O$-glycan chains [104]. In particular, CD43 can express carbohydrate structures, such as the sialylLewis $^{\mathrm{x}}\left(\mathrm{SLe}^{\mathrm{x}}\right)$ epitope, a ligand for P- and E-selectin, which favour cell-cell interactions [112]. Simultaneous expression of different CD43 glycoforms on the cell surface suggests that they can finely regulate cell-cell interactions $[111,113,114]$. The CD43 extracellular domain can be cleaved by metalloprotease and serine protease from the cell surface of stimulated granulocytes and lymphocytes, and the soluble extracellular fragment can be detected in normal human sera [115-118]. The cytoplasmic domain is evolutionarily conserved; it is involved in signal transduction mediating the connection to the cytoskeleton through binding to ezrin, radixin and moesin (ERM) proteins and contains a nuclear localization signal (NLS), which explains the nuclear localization of CD43, and a proline-rich sequence resembling SH3 binding consensus [119-123]

CD43 expression on human embryonic stem cell (hESC)derived haematopoietic progenitors may suggest a role of CD43 in haematopoietic development [124]. Further, CD43 is involved in the regulation of cell activation, differentiation, adhesion, and migration and may play a role in immune response by modulating cell growth, survival, and apoptosis $[113,114,125]$. However, some functions attributed to CD43 seem to be contradictory. In fact, CD43 was found to play a proadhesive or an antiadhesive role, and to induce apoptosis or to protect cells against apoptosis $[113,114]$. Indeed, CD43 induced cellular adhesion through the binding to molecules such as E-selectin [126, 127], galectin-1 and galectin-3 [128], siglec-1 [129], M-ficolin [130], integrins [131], cell surface nucleolin [132], and ICAM-1 (intercellular adhesion molecule type 1) [133]. However, it was reported that the antiadhesive property of CD43 depends not only on the strong negative charge and the large extended structure of the extracellular region, but also on interaction of the cytoplasmic domain with the cytoskeleton [134]. Most of the studies concerning the CD43 signalling have been performed in haematopoietic cells as this glycoprotein has been considered for a long time an exclusive marker of leukocytes. Indeed, the CD43 intracytoplasmic tail is involved in cell signalling and regulation of surface expression of CD43 during processes such as cell migration and immunological synapse. In particular, the CD43 intracytoplasmic domain binds to the ERM adaptor proteins, which cross-link actin filaments to transmembrane proteins such as CD43, CD44, and ICAM-2 [121], and interacts with Src kinases and zeta-chain of CD3 upon CD43 activation [122].

A growing number of reports indicate that there is an association between CD43 and cancer. One reason for CD43 involvement in cancer development is that CD43 signalling induces the activation of $\beta$-catenin, NF- $\kappa \mathrm{B}[135,136]$, NFAT, and AP-1, which are prosurvival transcription factors that can promote tumorigenesis when deregulated [137, 138]. The first study concerning the expression of CD43 in tumour cells of nonhaematopoietic origin reported that CD43 was found in the colon carcinoma cell line COLO 205. Indeed, an aberrant CD43 glycoform with the apparent molecular 
weight of $200 \mathrm{kDa}$ was described in COLO 205 [139, 140]. Subsequently, CD43 glycoforms were detected in a variety of cancer cell lines $[139,141,142]$ and in different tumours of nonhaematopoietic origin, including lung, breast, and colon, and not in the normal counterparts [143-147]. Further, alterations of the CD43 glycosylation pattern were associated with severe immunodeficiency $[148,149]$. These findings indicate that an aberrant expression of CD43 glycoforms may have a role in cancer development [144, 145, 150, 151]. Indeed, in many types of cancer, $\mathrm{O}$-glycans show heterogeneity and altered levels and may generate unusual epitopes. For example, they can be highly sialylated, less sulphated, or truncated and contain the $\mathrm{T}$ and $\mathrm{Tn}$ antigens and their sialylated forms. These structural changes may have many biological and pathological effects because they influence the ligandreceptor binding that mediates the interactions of cancer cells with their microenvironment. Hence, these events interfere with the proliferation of the cells, their ability to invade and metastasise, and their interactions with lectins, adhesion molecules, and other cell surface receptors of immune cells $[31,42]$. For example, increased sialylation of $O$-glycans has been shown to be associated with the enhanced growth rate of breast cancer cells in transgenic mice [38], with sialyl-Tn being a poor prognosis marker for cancer patients. Increased sialylation has also been associated with metastatic potential of cancer cells [39]. Sialyl-Lewis structures that are present in CD43 are often overexpressed by cancer cells; in colon cancer patients, metastatic tumour cells expressed increased amounts of sialyl-Lewis ${ }^{\mathrm{a}}$, sialyl-Lewis ${ }^{\mathrm{x}}$, and sialyl-dimeric Lewis ${ }^{\mathrm{X}}$ as compared with primary tumour cells [28-30, 152, 153]. These sialyl-Lewis structures are ligands for selectins that are involved in the attachment of leukocytes to the endothelium, suggesting that cancer cells may use the sialylLewis ${ }^{\mathrm{x}}$-selectin-binding mechanism during tumour invasion and metastasis [154]. In fact, it has been found that high metastatic tumour cells expressing higher levels of sialylLewis antigens adhere more strongly to E-selectin expressing cells compared to their low metastatic counterparts $[155,156]$. In addition, CD43 is involved in tumour cell adhesion and in development of metastasis via interaction with its ligand ICAM-1 [142].

A feature of CD43 expression in nonhaematopoietic cancer cells is that it has an intracellular localization in contrast to cell membrane expression characteristic of leukocytes [146, 150]. Like in leukocytes, the CD43 extracellular domain in cancer cells is cleaved and stored inside the cell before exocytosis [140]. Moreover, processing of CD43 by $\gamma$-secretase results in a CD43 cytoplasmic tail fragment, containing a functional nuclear localization sequence interacting with the nuclear transporter protein Ran. CD43 cytoplasmic tail has been found to translocate to the nucleus and is involved in the regulation of apoptosis, given that inhibition of either its nuclear translocation or its release by gamma-secretase was found to be proapoptotic $[137,157,158]$. Consequently, abnormal glycosylation could modify the proteolytic processing of CD43 and, therefore, interfere with CD43 functionality.

\section{UN1 Monoclonal Antibody Recognizes Cancer-Associated CD43 Glycoforms}

Peculiar glycoforms of CD43 are recognized by the UN1 monoclonal antibody $(\mathrm{mAb})$, which was originally produced in our laboratory [159]. The UN1 mAb was selected for a high reactivity against human immature thymocytes (CD3dim) [159] and later shown to recognize an epitope of the $\mathrm{UN1} / \mathrm{CD} 43$ antigenic glycoprotein, which includes a GalNAc$O$-linked monosaccharide $[147,160,161]$. The UN1/CD43 antigen was shown to be expressed in some leukemic Tcell lines, such as HPB-ALL, H9, MOLT-4, and in human thymocytes and a subpopulation of peripheral blood CD4+ T-lymphocytes and not in other blood cells $[159,160,162,163]$. Moreover, the UN1/CD43 antigen was expressed at early stages of development in fetal tissues, including thymus, spleen, adrenal cortex, bronchial epithelium, and skin, and was downregulated during ontogenesis [164]. The involvement of UN1/CD43 glycoforms in oncogenesis was suggested by several findings. In fact, UN1/CD43 was detected in a variety of solid tumours, including breast, colon, gastric, and squamous cell lung carcinomas, while it was undetected in the corresponding normal tissues and benign lesions $[147,164$, 165]. In particular, the expression level of UN1/CD43 glycoforms in breast cancer cells increased with the progression stage of the disease [165]. In fact, UN1 was not expressed in normal cells and nonproliferative lesions, while it was poorly expressed in fibroadenoma, moderately expressed in atypical hyperplasia and in situ breast carcinoma (stage 0 of disease), and highly expressed in infiltrating breast carcinoma (stages I-III) with the highest expression level in metastatic lesions (stage IV) [165]. These results underscore a direct correlation between its expression and breast cancer progression. Due to the wide expression in fetal tissues and downregulation during ontogeny with reexpression in cancer cells, the UN1/CD43 glycoforms were considered an oncofetal antigen [164]. In this regard, UN1 represents an interesting marker of potential value for immunophenotyping studies and clinical applications in cancer diseases $[164,165]$, besides the usefulness for studies on the role of CD43 glycosylation in tumorigenesis [147].

\section{Conclusions}

It has been well known for a long time that glycosylation is a very significant posttranslational modification of many biologically important molecules and that aberrant glycosylation of glycan structures is a common feature of neoplastic transformation. Many clinical cancer biomarkers correspond to glycosylated molecules and the alterations in their glycan moieties can be utilized as a target to improve existing cancer biomarkers. Glycomics and glycoproteomics are needed for the discovery of new glycan biomarkers with better sensitivity and specificity for early detection of cancer, for evaluation of therapeutic efficacy of cancer treatment, and for assessment of prognosis. CD43 is a mucin-like sialoglycoprotein, considered for a long time an exclusive marker of leukocytes but subsequently, found to be expressed in cancers, showing 
altered glycosylations. The UN1 mAb identifying cancerassociated CD43 glycoforms may represent an interesting tool for diagnostic and therapeutic purposes.

\section{Conflict of Interests}

The authors declare that there is no conflict of interests regarding the publication of this paper.

\section{Acknowledgments}

Giuseppe Scala received grants from Ministero dell'Istruzione, dell'Università e della Ricerca (PON01_02782 and PON01_00862); Ministero della Salute (RF-2010-2306943); AIRC (IG-2009-9411). Camillo Palmieri received a grant from Ministero della Salute (GR-2009-1606801). The funders had no role in study design, data collection and analysis, decision to publish, or preparation of the paper.

\section{References}

[1] P. R. Crocker and T. Feizit, "Carbohydrate recognition systems: functional triads in cell-cell interactions," Current Opinion in Structural Biology, vol. 6, no. 5, pp. 679-691, 1996.

[2] T. Feizi, "Carbohydrate-mediated recognition systems in innate immunity," Immunological Reviews, vol. 173, pp. 79-88, 2000.

[3] H. J. Gabius, H. C. Siebert, S. André, J. Jiménez-Barbero, and H. Rüdiger, "Chemical biology of the sugar code," ChemBioChem, vol. 5, no. 6, pp. 740-764, 2004.

[4] A. Helenius and M. Aebi, "Intracellular functions of N-linked glycans," Science, vol. 291, no. 5512, pp. 2364-2369, 2001.

[5] K. Karlsson, "Meaning and therapeutic potential of microbial recognition of host glycoconjugates," Molecular Microbiology, vol. 29, no. 1, pp. 1-11, 1998.

[6] J. B. Lowe and J. D. Marth, "A genetic approach to mammalian glycan function," Annual Review of Biochemistry, vol. 72, pp. 643-691, 2003.

[7] R. Apweiler, H. Hermjakob, and N. Sharon, "On the frequency of protein glycosylation, as deduced from analysis of the SWISSPROT database," Biochimica et Biophysica Acta, vol. 1473, no. 1, pp. 4-8, 1999.

[8] R. G. Spiro, "Protein glycosylation: nature, distribution, enzymatic formation, and disease implications of glycopeptide bonds," Glycobiology, vol. 12, no. 4, pp. 43R-56R, 2002.

[9] R. D. Cummings, "The repertoire of glycan determinants in the human glycome," Molecular BioSystems, vol. 5, no. 10, pp. 10871104, 2009.

[10] A. Varki and J. B. Lowe, "Biological roles of glycans," in Essentials of Glycobiology, A. Varki, R. D. Cummings, J. D. Esko et al., Eds., 2009.

[11] A. Varki, H. H. Freeze, and V. D. Vacquier, "Glycans in development and systemic physiology," in Essentials of Glycobiology, A. Varki, R. D. Cummings, J. D. Esko et al., Eds., 2009.

[12] A. Varki, R. Kannagi, and B. P. Toole, "Glycosylation changes in cancer," in Essentials of Glycobiology, A. Varki, R. D. Cummings, J. D. Esko et al., Eds., 2009.

[13] A. Raedler and S. Schreiber, "Analysis of differentiation and transformation of cells by lectins," Critical Reviews in Clinical Laboratory Sciences, vol. 26, no. 2, pp. 153-193, 1988.
[14] Y. Cao, P. Stosiek, G. F. Springer, and U. Karsten, “ThomsenFriedenreich-related caubohydrate antigens in normal adult human tissues: a systematic and comparative study," Histochemistry and Cell Biology, vol. 106, no. 2, pp. 197-207, 1996.

[15] G. F. Springer, "Immunoreactive T and Tn epitopes in cancer diagnosis, prognosis, and immunotherapy," Journal of Molecular Medicine, vol. 75, no. 8, pp. 594-602, 1997.

[16] S. R. Kumar, E. R. Sauter, T. P. Quinn, and S. L. Deutscher, "Thomsen-Friedenreich and Tn antigens in nipple fluid: carbohydrate biomarkers for breast cancer detection," Clinical Cancer Research, vol. 11, no. 19, part 1, pp. 6868-6871, 2005.

[17] T. Ju, Y. Wang, R. P. Aryal et al., "Tn and sialyl-Tn antigens, aberrant O-glycomics as human disease markers," ProteomicsClinical Applications, vol. 7, no. 9-10, pp. 618-631, 2013.

[18] K. Terasawa, H. Furumoto, M. Kamada, and T. Aono, "Expression of Tn and sialyl-Tn antigens in the neoplastic transformation of uterine cervical epithelial cells," Cancer Research, vol. 56, no. 9, pp. 2229-2232, 1996.

[19] T. Kawaguchi, H. Takazawa, S. Imai et al., "Expression of Vicia villosa agglutinin (VVA)-binding glycoprotein in primary breast cancer cells in relation to lymphatic metastasis: is atypical MUC1 bearing Tn antigen a receptor of VVA?" Breast Cancer Research and Treatment, vol. 98, no. 1, pp. 31-43, 2006.

[20] T. Ju, G. S. Lanneau, T. Gautam et al., "Human tumor antigens Tn and sialyl Tn arise from mutations in Cosmc," Cancer Research, vol. 68, no. 6, pp. 1636-1646, 2008.

[21] S. Pinho, N. T. Marcos, B. Ferreira et al., "Biological significance of cancer-associated sialyl-Tn antigen: modulation of malignant phenotype in gastric carcinoma cells," Cancer Letters, vol. 249, no. 2, pp. 157-170, 2007.

[22] I. Brockhausen, J. Yang, N. Dickinson, S. Ogata, and S. H. Itzkowitz, "Enzymatic basis for sialyl-Tn expression in human colon cancer cells," Glycoconjugate Journal, vol. 15, no. 6, pp. 595-603, 1998.

[23] F. Safi, W. Schlosser, G. Kolb, and H. G. Beger, "Diagnostic value of CA 19-9 in patients with pancreatic cancer and nonspecific gastrointestinal symptoms," Journal of Gastrointestinal Surgery, vol. 1, no. 2, pp. 106-112, 1997.

[24] G. Y. Locker, S. Hamilton, J. Harris et al., "ASCO 2006 update of recommendations for the use of tumor markers in gastrointestinal cancer," Journal of Clinical Oncology, vol. 24, no. 33, pp. 5313-5327, 2006.

[25] W. Reiter, P. Stieber, C. Reuter et al., "Prognostic value of preoperative serum levels of CEA, CA 19-9 and CA 72-4 in gastric carcinoma," Anticancer Research, vol. 17, no. 4, pp. 29032906, 1997.

[26] M. Ychou, J. Duffour, A. Kramar, S. Gourgou, and J. Grenier, "Clinical significance and prognostic value of CA72-4 compared with CEA and CA19-9 in patients with gastric cancer," Disease Markers, vol. 16, no. 3-4, pp. 105-110, 2000.

[27] N. Duraker and A. N. Elk, "The prognostic significance of preoperative serum CA 19-9 in patients with resectable gastric carcinoma: comparison with CEA," Journal of Surgical Oncology, vol. 76, no. 4, pp. 266-271, 2001.

[28] S. Nakamori, M. Kameyama, S. Imaoka et al., "Increased expression of sialyl Lewis(x) antigen correlates with poor survival in patients with colorectal carcinoma: clinicopathological and immunohistochemical study," Cancer Research, vol. 53, no. 15, pp. 3632-3637, 1993

[29] S. Nishihara, T. Hiraga, Y. Ikehara et al., "Molecular mechanisms of expression of Lewis b antigen and other type I Lewis antigens 
in human colorectal cancer," Glycobiology, vol. 9, no. 6, pp. 607616, 1999.

[30] A. Konno, Y. Hoshino, S. Terashima, R. Motoki, and T. Kawaguchi, "Carbohydrate expression profile of colorectal cancer cells is relevant to metastatic pattern and prognosis," Clinical and Experimental Metastasis, vol. 19, no. 1, pp. 61-70, 2002.

[31] I. Brockhausen, "Mucin-type O-glycans in human colon and breast cancer: glycodynamics and functions," EMBO Reports, vol. 7, no. 6, pp. 599-604, 2006.

[32] N. Taniguchi, E. Miyoshi, J. H. Ko, Y. Ikeda, and Y. Ihara, "Implication of $\mathrm{N}$-acetylglucosaminyltransferases III and V in cancer: gene regulation and signaling mechanism," Biochimica et Biophysica Acta, vol. 1455, no. 2-3, pp. 287-300, 1999.

[33] J. W. Dennis, S. Laferte, and C. Waghorne, “ $\beta 1-6$ branching of Asn-linked oligosaccharides is directly associated with metastasis," Science, vol. 236, no. 4801, pp. 582-585, 1987.

[34] K. Noda, E. Miyoshi, J. Gu et al., "Relationship between elevated FX expression and increased production of GDP-L-fucose, a common donor substrate for fucosylation in human hepatocellular carcinoma and hepatoma cell lines," Cancer Research, vol. 63, no. 19, pp. 6282-6289, 2003.

[35] E. Miyoshi, K. Noda, Y. Yamaguchi et al., "The alphal-6fucosyltransferase gene and its biological significance," Biochimica et Biophysica Acta, vol. 1473, no. 1, pp. 9-20, 1999.

[36] Y. Ito, A. Miyauchi, H. Yoshida et al., "Expression of $\alpha 1,6-$ fucosyltransferase (FUT8) in papillary carcinoma of the thyroid: its linkage to biological aggressiveness and anaplastic transformation," Cancer Letters, vol. 200, no. 2, pp. 167-172, 2003.

[37] D. Li, T. Mallory, and S. Satomura, "AFP-L3: a new generation of tumor marker for hepatocellular carcinoma," Clinica Chimica Acta, vol. 313, no. 1-2, pp. 15-19, 2001.

[38] A. Mungul, L. Cooper, I. Brockhausen et al., "Sialylated core 1 based O-linked glycans enhance the growth rate of mammary carcinoma cells in MUC1 transgenic mice," International Journal of Oncology, vol. 25, no. 4, pp. 937-943, 2004.

[39] R. S. Bresalier, S. B. Ho, H. L. Schoeppner et al., "Enhanced sialylation of mucin-associated carbohydrate structures in human colon cancer metastasis," Gastroenterology, vol. 110, no. 5, pp. 1354-1367, 1996.

[40] S. Hakomori, "Aberrant glycosylation in tumors and tumorassociated carbohydrate antigens," Advances in Cancer Research, vol. 52, pp. 257-331, 1989.

[41] S. I. Hakomori and R. D. Cummings, "Glycosylation effects on cancer development," Glycoconjugate Journal, vol. 29, no. 8-9, pp. 565-566, 2012.

[42] K. Ohtsubo and J. D. Marth, "Glycosylation in cellular mechanisms of health and disease," Cell, vol. 126, no. 5, pp. 855-867, 2006.

[43] S. I. Do, K. Kim, D. H. Kim et al., "Associations between the expression of mucins (MUC1, MUC2, MUC5AC, and MUC6) and clinicopathologic parameters of human breast ductal carcinomas," Journal of Breast Cancer, vol. 16, no. 2, pp. 152-158, 2013.

[44] D. W. Kufe, "Mucins in cancer: function, prognosis and therapy," Nature Reviews Cancer, vol. 9, no. 12, pp. 874-885, 2009.

[45] M. A. Hollingsworth and B. J. Swanson, "Mucins in cancer: protection and control of the cell surface," Nature Reviews Cancer, vol. 4, no. 1, pp. 45-60, 2004.

[46] Y. S. Kim, J. Gum Jr., and I. Brockhausen, "Mucin glycoproteins in neoplasia," Glycoconjugate Journal, vol. 13, no. 5, pp. 693-707, 1996.
[47] S. Tsuboi, S. Hatakeyama, C. Ohyama, and M. Fukuda, "Two opposing roles of O-glycans in tumor metastasis," Trends in Molecular Medicine, vol. 18, no. 4, pp. 224-232, 2012.

[48] T. Kjeldsen, H. Clausen, S. Hirohashi, T. Ogawa, H. Iijima, and S. Hakomori, "Preparation and characterization of monoclonal antibodies directed to the tumor-associated O-linked sialosyl$2 \rightarrow 6 \alpha$-N-acetylgalactosaminyl (sialosyl-Tn) epitope," Cancer Research, vol. 48, no. 8, pp. 2214-2220, 1988.

[49] M. Dalziel, C. Whitehouse, I. McFarlane et al., "The relative activities of the C2GnT1 and ST3Gal-I glycosyltransferases determine O-glycan structure and expression of a tumorassociated epitope on MUC1," The Journal of Biological Chemistry, vol. 276, no. 14, pp. 11007-11015, 2001.

[50] N. T. Marcos, A. Cruz, F. Silva et al., "Polypeptide GalNActransferases, ST6GalNAc-transferase I, and ST3Gal-transferase I expression in gastric carcinoma cell lines," Journal of Histochemistry and Cytochemistry, vol. 51, no. 6, pp. 761-771, 2003.

[51] Y. Tian and H. Zhang, "Characterization of disease-associated N-linked glycoproteins," Proteomics, vol. 13, no. 3-4, pp. 504-511, 2013.

[52] R. R. Drake, E. E. Schwegler, G. Malik et al., "Lectin capture strategies combined with mass spectrometry for the discovery of serum glycoprotein biomarkers," Molecular and Cellular Proteomics, vol. 5, no. 10, pp. 1957-1967, 2006.

[53] T. Ishihara, I. Fukuda, A. Morita et al., "Development of quantitative plasma $\mathrm{N}$-glycoproteomics using label-free 2-D LC-MALDI MS and its applicability for biomarker discovery in hepatocellular carcinoma," Journal of Proteomics, vol. 74, no. 10, pp. 2159-2168, 2011.

[54] X. Zeng, B. L. Hood, M. Sun et al., "Lung cancer serum biomarker discovery using glycoprotein capture and liquid chromatography mass spectrometry," Journal of Proteome Research, vol. 9, no. 12, pp. 6440-6449, 2010.

[55] Y. Tian, Z. Yao, R. B. S. Roden, and H. Zhang, "Identification of glycoproteins associated with different histological subtypes of ovarian tumors using quantitative glycoproteomics," Proteomics, vol. 11, no. 24, pp. 4677-4687, 2011.

[56] R. Chen, Y. Tan, M. Wang et al., "Development of glycoprotein capture-based label-free method for the high-throughput screening of differential glycoproteins in hepatocellular carcinoma," Molecular \& Cellular Proteomics, vol. 10, no. 7, Article ID M110.006445, 2011.

[57] Y. Tian, G. S. Bova, and H. Zhang, "Quantitative glycoproteomic analysis of optimal cutting temperature-embedded frozen tissues identifying glycoproteins associated with aggressive prostate cancer," Analytical Chemistry, vol. 83, no. 18, pp. 70137019, 2011.

[58] Y. Zhao, Y. Sato, T. Isaji et al., "Branched N-glycans regulate the biological functions of integrins and cadherins," FEBS Journal, vol. 275, no. 9, pp. 1939-1948, 2008.

[59] H. Schachter, "Biosynthetic controls that determine the branching and microheterogeneity of protein-bound oligosaccharides," Advances in Experimental Medicine and Biology, vol. 205, pp. 53-85, 1986.

[60] M. Yoshimura, A. Nishikawa, Y. Ihara, S. Taniguchi, and N. Taniguchi, "Suppression of lung metastasis of B16 mouse melanoma by $\mathrm{N}$-acetylglucosaminyltransferase III gene transfection," Proceedings of the National Academy of Sciences of the United States of America, vol. 92, no. 19, pp. 8754-8758, 1995.

[61] S. H. Lee, M. Takahashi, K. Honke et al., "Loss of core fucosylation of low-density lipoprotein receptor-related protein-1 
impairs its function, leading to the upregulation of serum levels of insulin-like growth factor-binding protein 3 in Fut8-/- mice," Journal of Biochemistry, vol. 139, no. 3, pp. 391-398, 2006.

[62] Y. Shibukawa, M. Takahashi, I. Laffont, K. Honke, and N. Taniguchi, "Down-regulation of hydrogen peroxide-induced PKC $\delta$ activation in $\mathrm{N}$-acetylglucosaminyltransferase IIItransfected HeLaS3 cells," The Journal of Biological Chemistry, vol. 278, no. 5, pp. 3197-3203, 2003.

[63] S. Nadanaka, C. Sato, K. Kitajima, K. Katagiri, S. Irie, and T. Yamagata, "Occurrence of oligosialic acids on integrin $\alpha 5$ subunit and their involvement in cell adhesion to fibronectin," The Journal of Biological Chemistry, vol. 276, no. 36, pp. 3365733664, 2001.

[64] E. Miyoshi, M. Terao, and Y. Kamada, "Physiological roles of N-acetylglucosaminyltransferase $\mathrm{V}(\mathrm{GnT}-\mathrm{V})$ in mice," $B M B$ Reports, vol. 45, no. 10, pp. 554-559, 2012.

[65] K. S. Lau and J. W. Dennis, "N-Glycans in cancer progression," Glycobiology, vol. 18, no. 10, pp. 750-760, 2008.

[66] B. W. T. Yin and K. O. Lloyd, "Molecular cloning of the CA125 ovarian cancer antigen: identification as a new mucin, MUC16," The Journal of Biological Chemistry, vol. 276, no. 29, pp. 2737127375, 2001.

[67] K. Nustad, R. C. Bast Jr., T. J. O’Brien et al., "Specificity and affinity of 26 monoclonal antibodies against the CA 125 antigen: first report from the ISOBM TD-1 workshop," Tumor Biology, vol. 17, no. 4, pp. 196-219, 1996.

[68] T. J. O'Brien, J. B. Beard, L. J. Underwood, R. A. Dennis, A. D. Santin, and L. York, "The CA 125 gene: an extracellular superstructure dominated by repeat sequences," Tumor Biology, vol. 22, no. 6, pp. 348-366, 2001.

[69] B. W. T. Yin, A. Dnistrian, and K. O. Lloyd, "Ovarian cancer antigen CA125 is encoded by the MUC16 mucin gene," International Journal of Cancer, vol. 98, no. 5, pp. 737-740, 2002.

[70] A. Chang, J. Cai, G. Miranda, S. Groshen, D. Skinner, and J. P. Stein, "Usefulness of CA 125 as a preoperative prognostic marker for transitional cell carcinoma of the bladder," Journal of Urology, vol. 172, no. 6, part 1, pp. 2182-2186, 2004.

[71] J. Schneider, "Tumor markers in detection of lung cancer," Advances in Clinical Chemistry, vol. 42, pp. 1-41, 2006.

[72] D. Baskić, P. Ristić, S. Matić, D. Banković, S. Popović, and N. Arsenijević, "Clinical evaluation of the simultaneous determination of CA 15-3, CA 125 and sHER2 in breast cancer," Biomarkers, vol. 12, no. 6, pp. 657-667, 2007.

[73] A. Sevinc, M. Adli, M. E. Kalender, and C. Camci, "Benign causes of increased serum CA-125 concentration," The Lancet Oncology, vol. 8, no. 12, pp. 1054-1055, 2007.

[74] L. Harris, H. Fritsche, R. Mennel et al., "American society of clinical oncology 2007 update of recommendations for the use of tumor markers in breast cancer," Journal of Clinical Oncology, vol. 25, no. 33, pp. 5287-5312, 2007.

[75] V. R. Zurawski Jr., H. Orjaseter, A. Andersen, and E. Jellum, "Elevated serum CA 125 levels prior to diagnosis of ovarian neoplasia: relevance for early detection of ovarian cancer," International Journal of Cancer, vol. 42, no. 5, pp. 677-680, 1988.

[76] R. C. Bast Jr., T. L. Klug, E. St John et al., "A radioimmunoassay using a monoclonal antibody to monitor the course of epithelial ovarian cancer," The New England Journal of Medicine, vol. 309, no. 15 , pp. 883-887, 1983.

[77] D. K. Pauler, U. Menon, M. McIntosh, H. L. Symecko, S. J. Skates, and I. J. Jacobs, "Factors influencing serum CA125II levels in healthy postmenopausal women," Cancer Epidemiology Biomarkers and Prevention, vol. 10, no. 5, pp. 489-493, 2001.
[78] B. S. Gostout and M. A. Brewer, "Guidelines for referral of the patient with an adnexal mass," Clinical Obstetrics and Gynecology, vol. 49, no. 3, pp. 448-458, 2006.

[79] R. C. Bast Jr., D. Badgwell, Z. Lu et al., "New tumor markers: CA125 and beyond," International Journal of Gynecological Cancer, vol. 15, no. 6, pp. 274-281, 2005.

[80] F. G. Ebeling, P. Stieber, M. Untch et al., "Serum CEA and CA 15-3 as prognostic factors in primary breast cancer," The British Journal of Cancer, vol. 86, no. 8, pp. 1217-1222, 2002.

[81] E. J. Kumpulainen, R. J. Keskikuru, and R. T. Johansson, “Serum tumor marker CA 15.3 and stage are the two most powerful predictors of survival in primary breast cancer," Breast Cancer Research and Treatment, vol. 76, no. 2, pp. 95-102, 2002.

[82] M. Uehara, T. Kinoshita, T. Hojo, S. Akashi-Tanaka, E. Iwamoto, and T. Fukutomi, "Long-term prognostic study of carcinoembryonic antigen (CEA) and carbohydrate antigen 15-3 (CA 15-3) in breast cancer," International Journal of Clinical Oncology, vol. 13, no. 5, pp. 447-451, 2008.

[83] S. Lauro, L. Trasatti, F. Bordin et al., "Comparison of CEA, MCA, CA 15-3 and CA 27-29 in follow-up and monitoring therapeutic response in breast cancer patients," Anticancer Research, vol. 19, no. 4, pp. 3511-3515, 1999.

[84] D. Marrelli, E. Pinto, A. de Stefano et al., "Preoperative positivity of serum tumor markers is a strong predictor of hematogenous recurrence of gastric cancer," Journal of Surgical Oncology, vol. 78, no. 4, pp. 253-258, 2001.

[85] M. Carpelan-Holmström, J. Louhimo, U. H. Stenman, H. Alfthan, H. Järvinen, and C. Haglund, "Estimating the probability of cancer with several tumor markers in patients with colorectal disease," Oncology, vol. 66, no. 4, pp. 296-302, 2004.

[86] D. Mazal, R. Lo-Man, S. Bay et al., "Monoclonal antibodies toward different Tn-amino acid backbones display distinct recognition patterns on human cancer cells. Implications for effective immuno-targeting of cancer," Cancer Immunology, Immunotherapy, vol. 62, no. 6, pp. 1107-1122, 2013.

[87] J. Louhimo, A. Kokkola, H. Alfthan, U. Stenman, and C. Haglund, "Preoperative hCG $\beta$ and CA 72-4 are prognostic factors in gastric cancer," International Journal of Cancer, vol. 111, no. 6, pp. 929-933, 2004.

[88] J. Louhimo, H. Alfthan, U. H. Stenman, and C. Haglund, "Serum HCG $\beta$ and CA 72-4 are stronger prognostic factors than CEA, CA 19-9 and CA 242 in pancreatic cancer," Oncology, vol. 66, no. 2, pp. 126-131, 2004.

[89] K. J. Lee, S. W. Yi, M. J. Chung et al., "Serum CA 19-9 and CEA levels as a prognostic factor in pancreatic adenocarcinoma," Yonsei Medical Journal, vol. 54, no. 3, pp. 643-649, 2013.

[90] M. Haas, V. Heinemann, F. Kullmann et al., "Prognostic value of CA 19-9, CEA, CRP, LDH and bilirubin levels in locally advanced and metastatic pancreatic cancer: results from a multicenter, pooled analysis of patients receiving palliative chemotherapy," Journal of Cancer Research and Clinical Oncology, vol. 139, no. 4, pp. 681-689, 2013.

[91] M. Grunnet and J. B. Sorensen, "Carcinoembryonic antigen (CEA) as tumor marker in lung cancer," Lung Cancer, vol. 76, no. 2, pp. 138-143, 2012.

[92] C. Ilantzis, L. Demarte, R. A. Screaton, and C. P. Stanners, "Deregulated expression of the human tumor marker CEA and CEA family member CEACAM6 disrupts tissue architecture and blocks colonocyte differentiation," Neoplasia, vol. 4, no. 2, pp. 151-163, 2002.

[93] D. S. A. Sanders and M. A. Kerr, "Lewis blood group and CEA related antigens; coexpressed cell-cell adhesion molecules 
with roles in the biological progression and dissemination of tumours," Journal of Clinical Pathology-Molecular Pathology, vol. 52, no. 4, pp. 174-178, 1999.

[94] R. H. Fletcher, "Carcinoembryonic antigen," Annals of Internal Medicine, vol. 104, no. 1, pp. 66-73, 1986.

[95] M. J. Goldstein and E. P. Mitchell, "Carcinoembryonic antigen in the staging and follow-up of patients with colorectal cancer," Cancer Investigation, vol. 23, no. 4, pp. 338-351, 2005.

[96] E. A. Bakalakos, W. E. Burak Jr., D. C. Young, and E. W. Martin Jr., "Is carcino-embryonic antigen useful in the followup management of patients with colorectal liver metastases," The American Journal of Surgery, vol. 177, no. 1, pp. 2-6, 1999.

[97] S. R. Carlsson and M. Fukuda, "Isolation and characterization of leukosialin, a major sialoglycoprotein on human leukocytes," The Journal of Biological Chemistry, vol. 261, no. 27, pp. 1277912786, 1986.

[98] M. Fukuda and S. R. Carlsson, "Leukosialin, a major sialoglycoprotein on human leukocytes as differentiation antigens," Medical Biology, vol. 64, no. 6, pp. 335-343, 1986.

[99] E. Remold-O’Donnell, C. Zimmerman, D. Kenney, and F. S. Rosen, "Expression on blood cells of sialophorin, the surface glycoprotein that is defective in Wiskott-Aldrich syndrome," Blood, vol. 70, no. 1, pp. 104-109, 1987.

[100] M. Wiken, P. Bjorck, B. Axelsson, and P. Perlmann, "Induction of CD43 expression during activation and terminal differentiation of human B cells," Scandinavian Journal of Immunology, vol. 28 , no. 4 , pp. 457-464, 1988.

[101] M. Fukuda, "Leukosialin, a major O-glycan-containing sialoglycoprotein defining leukocyte differentiation and malignancy," Glycobiology, vol. 1, no. 4, pp. 347-356, 1991.

[102] T. Moore, S. Huang, L. W. M. M. Terstappen, M. Bennett, and V. Kumar, "Expression of CD43 on murine and human pluripotent hematopoietic stem cells," Journal of Immunology, vol. 153, no. 11, pp. 4978-4987, 1994.

[103] R. R. Hardy, C. E. Carmack, S. A. Shinton, J. D. Kemp, and K. Hayakawa, "Resolution and characterization of pro-B and prepro-B cell stages in normal mouse bone marrow," Journal of Experimental Medicine, vol. 173, no. 5, pp. 1213-1225, 1991.

[104] C. S. Shelley, E. Remold-O’Donnell, A. E. Davis III et al., "Molecular characterization of sialophorin (CD43), the lymphocyte surface sialoglycoprotein defective in Wiskott-Aldrich syndrome," Proceedings of the National Academy of Sciences of the United States of America, vol. 86, no. 8, pp. 2819-2823, 1989.

[105] A. Pallant, A. Eskenazi, M. G. Mattei et al., "Characterization of cDNAs encoding human leukosialin and localization of the leukosialin gene to chromosome 16," Proceedings of the National Academy of Sciences of the United States of America, vol. 86, no. 4, pp. 1328-1332, 1989.

[106] J. G. Cyster, D. M. Shotton, and A. F. Williams, "The dimensions of the T lymphocyte glycoprotein leukosialin and identification of linear protein epitopes that can be modified by glycosylation," EMBO Journal, vol. 10, no. 4, pp. 893-902, 1991.

[107] J. Cyster, C. Somoza, N. Killeen, and A. F. Williams, "Protein sequence and gene structure for mouse leukosialin (CD43), a T lymphocyte mucin without introns in the coding sequence," European Journal of Immunology, vol. 20, no. 4, pp. 875-881, 1990.

[108] S. R. Carlsson, H. Sasaki, and M. Fukuda, "Structural variations of O-linked oligosaccharides present in leukosialin isolated from erythroid, myeloid, and T-lymphoid cell lines," The Journal of Biological Chemistry, vol. 261, no. 27, pp. 12787-12795, 1986.
[109] M. Fukuda and S. Tsuboi, "Mucin-type O-glycans and leukosialin," Biochimica et Biophysica Acta, vol. 1455, no. 2-3, pp. 205-217, 1999.

[110] E. Remold-O’Donnell, D. Kenney, and F. S. Rosen, "Biosynthesis of human sialophorins and analysis of the polypeptide core," Biochemistry, vol. 26, no. 13, pp. 3908-3913, 1987.

[111] T. J. Brown, W. W. Shuford, W. C. Wang et al., "Characterization of a CD43/leukosialin-mediated pathway for inducing apoptosis in human T-lymphoblastoid cells," The Journal of Biological Chemistry, vol. 271, no. 44, pp. 27686-27695, 1996.

[112] K. Maemura and M. Fukuda, "Poly-N-acetyllactosaminyl Oglycans attached to leukosialin. The presence of sialyl $\operatorname{Le}(\mathrm{x})$ structures in O-glycans," The Journal of Biological Chemistry, vol. 267, no. 34, pp. 24379-24386, 1992.

[113] G. Pedraza-Alva and Y. Rosenstein, "CD43-one molecule, many tales to recount," Signal Transduction, vol. 7, no. 5-6, pp. 372-385, 2007.

[114] J. R. Ostberg, R. K. Barth, and J. G. Frelinger, "The Roman god Janus: a paradigm for the function of CD43," Immunology Today, vol. 19, no. 12, pp. 546-550, 1998.

[115] K. Schmid, M. A. Hediger, R. Brossmer et al., "Amino acid sequence of human plasma galactoglycoprotein: identity with the extracellular region of CD43 (sialophorin)," Proceedings of the National Academy of Sciences of the United States of America, vol. 89, no. 2, pp. 663-667, 1992.

[116] V. Bazil and J. L. Strominger, "CD43, the major sialoglycoprotein of human leukocytes, is proteolytically cleaved from the surface of stimulated lymphocytes and granulocytes," Proceedings of the National Academy of Sciences of the United States of America, vol. 90, no. 9, pp. 3792-3796, 1993.

[117] V. Bažil and J. L. Strominger, "Metalloprotease and serine protease are involved in cleavage of CD43, CD44, and CD16 from stimulated human granulocytes: induction of cleavage of L-selectin via CD16," Journal of Immunology, vol. 152, no. 3, pp. 1314-1322, 1994.

[118] E. Remold-O’Donnell and D. Parent, “Two proteolytic pathways for down-regulation of the barrier molecule CD43 of human neutrophils," Journal of Immunology, vol. 152, no. 7, pp. 35953605, 1994

[119] S. Yonemura, M. Hirao, Y. Doi et al., "Ezrin/radixin/moesin (ERM) proteins bind to a positively charged amino acid cluster in the juxta-membrane cytoplasmic domain of CD44, CD43, and ICAM-2," Journal of Cell Biology, vol. 140, no. 4, pp. 885895, 1998.

[120] M. E. Cruz-Muñoz, E. Salas-Vidal, N. Salaiza-Suazo, I. Becker, G. Pedraza-Alva, and Y. Rosenstein, "The CD43 coreceptor molecule recruits the $\zeta$-chain as part of its signaling pathway," Journal of Immunology, vol. 171, no. 4, pp. 1901-1908, 2003.

[121] S. Yonemura, A. Nagafuchi, N. Sato, and S. Tsukita, "Concentration of an integral membrane protein, CD43 (leukosialin, sialophorin), in the cleavage furrow through the interaction of its cytoplasmic domain with actin-based cytoskeletons," Journal of Cell Biology, vol. 120, no. 2, pp. 437-449, 1993.

[122] G. Pedraza-Alva, L. B. Mérida, S. J. Burakoff, and Y. Rosenstein, "T cell activation through the CD43 molecule leads to Vav tyrosine phosphorylation and mitogen-activated protein kinase pathway activation," The Journal of Biological Chemistry, vol. 273, no. 23, pp. 14218-14224, 1998.

[123] E. J. Allenspach, P. Cullinan, J. Tong et al., "ERM-dependent movement of CD43 defines a novel protein complex distal to the immunological synapse," Immunity, vol. 15, no. 5, pp. 739750, 2001. 
[124] M. A. Vodyanik, J. A. Thomson, and I. I. Slukvin, "Leukosialin (CD43) defines hematopoietic progenitors in human embryonic stem cell differentiation cultures," Blood, vol. 108, no. 6, pp. 2095-2105, 2006.

[125] Y. Rosenstein, A. Santana, and G. Pedraza-Alva, "CD43, a molecule with multiple functions," Immunologic Research, vol. 20, no. 2, pp. 89-99, 1999.

[126] R. C. Fuhlbrigge, S. L. King, R. Sackstein, and T. S. Kupper, "CD43 is a ligand for E-selectin on CLA+ human T cells," Blood, vol. 107, no. 4, pp. 1421-1426, 2006.

[127] M. Matsumoto, K. Atarashi, E. Umemoto et al., "CD43 functions as a ligand for E-selectin on activated T cells," Journal of Immunology, vol. 175, no. 12, pp. 8042-8050, 2005.

[128] R. Y. Yang, G. A. Rabinovich, and F. T. Liu, "Galectins: structure, function and therapeutic potential," Expert Reviews in Molecular Medicine, vol. 10, article e17, 2008.

[129] T. K. van den Berg, D. Nath, H. J. Ziltener et al., "Cutting edge: CD43 functions as a T cell counterreceptor for the macrophage adhesion receptor sialoadhesin (Siglec-1)," Journal of Immunology, vol. 166, no. 6, pp. 3637-3640, 2001.

[130] A. N. Moreno-Amaral, E. Gout, C. Danella-Polli et al., "Mficolin and leukosialin (CD43): new partners in neutrophil adhesion," Journal of Leukocyte Biology, vol. 91, no. 3, pp. 469474, 2012.

[131] P. Sanchez-Mateos, M. R. Campanero, M. A. del Pozo, and F. Sanchez-Madrid, "Regulatory role of CD43 leukosialin on integrin-mediated T-cell adhesion to endothelial and extracellular matrix ligands and its polar redistribution to a cellular uropod," Blood, vol. 86, no. 6, pp. 2228-2239, 1995.

[132] K. Hirano, Y. Miki, Y. Hirai et al., "A multifunctional shuttling protein nucleolin is a macrophage receptor for apoptotic cells," The Journal of Biological Chemistry, vol. 280, no. 47, pp. 3928439293, 2005.

[133] Y. Rosenstein, J. K. Park, W. C. Hahn, F. S. Rosen, B. E. Bierer, and S. J. Burakoff, "CD43, a molecule defective in WiskottAldrich syndrome, binds ICAM-1," Nature, vol. 354, no. 6350, pp. 233-235, 1991.

[134] J. Walker and J. M. Green, "Structural requirements for CD43 function," Journal of Immunology, vol. 162, no. 7, pp. 4109-4114, 1999.

[135] G. Fiume, A. Rossi, A. de Laurentiis et al., "Eukaryotic initiation factor $4 \mathrm{H}$ is under transcriptional control of p65/NF- $\kappa \mathrm{B}$," PLoS ONE, vol. 8, no. 6, Article ID e66087, 2013.

[136] G. Fiume, E. Vecchio, A. de Laurentiis et al., "Human immunodeficiency virus-1 Tat activates NF- $\kappa$ B via physical interaction with I $\kappa$ B- $\alpha$ and p65," Nucleic Acids Research, vol. 40, no. 8, pp. 3548-3562, 2012.

[137] C. X. Andersson, J. Fernandez-Rodriguez, S. Laos, D. Baeckström, C. Haass, and G. C. Hansson, "Shedding and $\gamma$ secretase-mediated intramembrane proteolysis of the mucintype molecule CD43," Biochemical Journal, vol. 387, no. 2, pp. 377-384, 2005.

[138] M. A. Santana, G. Pedraza-Alva, N. Olivares-Zavaleta et al., "CD43-mediated signals induce DNA binding activity of AP1, NF-AT and NF $\kappa$ B transcription factors in human T lymphocytes," The Journal of Biological Chemistry, vol. 275, no. 40, pp. 31460-31468, 2000.

[139] D. Baeckstrom, K. Zhang, N. Asker, U. Ruetschi, M. Ek, and G. C. Hansson, "Expression of the leukocyte-associated sialoglycoprotein CD43 by a colon carcinoma cell line," The Journal of Biological Chemistry, vol. 270, no. 23, pp. 1368813692, 1995.
[140] D. Baeckström, "Post-translational fate of a mucin-like leukocyte sialoglycoprotein (CD43) aberrantly expressed in a colon carcinoma cell line," The Journal of Biological Chemistry, vol. 272, no. 17, pp. 11503-11509, 1997.

[141] J. Fernandez-Rodriguez, C. X. Andersson, S. Laos et al., “The leukocyte antigen CD43 is expressed in different cell lines of nonhematopoietic origin," Tumor Biology, vol. 23, no. 4, pp. 193201, 2002.

[142] P. Ziprin, N. A. Alkhamesi, P. F. Ridgway, D. H. Peck, and A. W. Darzi, “Tumour-expressed CD43 (sialophorin) mediates tumour-mesothelial cell adhesion," Biological Chemistry, vol. 385, no. 8, pp. 755-761, 2004.

[143] A. Pimenidou, L. A. Madden, K. P. Topping, K. A. Smith, J. R. T. Monson, and J. Greenman, "Novel CD43 specific phage antibodies react with early stage colorectal tumours," Oncology Reports, vol. 11, no. 2, pp. 327-331, 2004.

[144] M. Santamaría, A. López-Beltrán, M. Toro, J. Peña, and I. J. Molina, "Specific monoclonal antibodies against leukocyte-restricted cell surface molecule CD43 react with nonhematopoietic tumor cells," Cancer Research, vol. 56, no. 15, pp. 3526-3529, 1996.

[145] R. Sikut, O. Nilsson, D. Baeckström, and G. C. Hansson, "Colon adenoma and cancer cells aberrantly express the leukocyteassociated sialoglycoprotein CD43," Biochemical and Biophysical Research Communications, vol. 238, no. 2, pp. 612-616, 1997.

[146] Q. Fu, S. E. Cash, J. J. Andersen et al., "CD43 in the nucleus and cytoplasm of lung cancer is a potential therapeutic target," International Journal of Cancer, vol. 132, no. 8, pp. 1761-1770, 2013.

[147] A. de Laurentiis, M. Gaspari, C. Palmieri et al., "Mass spectrometry-based identification of the tumor antigen UN1 as the transmembrane CD43 sialoglycoprotein," Molecular and Cellular Proteomics, vol. 10, no. 5, Article ID M111.007898, 2011.

[148] J. Lefebvre, V. Giordanengo, M. Limouse et al., "Altered glycosylation of leukosialin, CD43, in HIV-1-infected cells of the CEM line," Journal of Experimental Medicine, vol. 180, no. 5, pp. 16091617, 1994.

[149] S. Khan, S. Holding, P. C. Doré, and W. A. C. Sewell, "Abnormal O-glycosylation of CD43 may account for some features of Wiskott-Aldrich syndrome," Medical Hypotheses, vol. 70, no. 2, pp. 269-272, 2008.

[150] R. Sikut, C. X. Andersson, A. Sikut, J. Fernandez-Rodriguez, N. G. Karlsson, and G. C. Hansson, "Detection of CD43 (leukosialin) in colon adenoma and adenocarcinoma by novel monoclonal antibodies against its intracellular domain," International Journal of Cancer, vol. 82, no. 1, pp. 52-58, 1999.

[151] J. Fernandez-Rodriguez, O. Dwir, R. Alon, and G. C. Hansson, "Tumor cell MUC1 and CD43 are glycosylated differently with sialyl-Lewis a and $\mathrm{x}$ epitopes and show variable interactions with E-selectin under physiological flow conditions," Glycoconjugate Journal, vol. 18, no. 11-12, pp. 925-930, 2001.

[152] K. Shimodaira, J. Nakayama, N. Nakamura, O. Hasebe, T. Katsuyama, and M. Fukuda, "Carcinoma-associated expression of core $2 \beta-1,6-\mathrm{N}$-acetylglucosaminlytransferase gene in human colorectal cancer: role of O-glycans in tumor progression," Cancer Research, vol. 57, no. 23, pp. 5201-5206, 1997.

[153] T. Petretti, W. Kemmner, B. Schulze, and P. M. Schlag, "Altered mRNA expression of glycosyltransferases in human colorectal carcinomas and liver metastases," Gut, vol. 46, no. 3, pp. 359366, 2000.

[154] N. Kojima, K. Handa, W. Newman, and S. Hakomori, "Inhibition of selectin-dependent tumor cell adhesion to endothelial 
cells and platelets by blocking O-glycosylation of these cells," Biochemical and Biophysical Research Communications, vol. 182, no. 3, pp. 1288-1295, 1992.

[155] R. Sawada, S. Tsuboi, and M. Fukuda, "Differential E-selectindependent adhesion efficiency in sublines of a human colon cancer exhibiting distinct metastatic potentials," The Journal of Biological Chemistry, vol. 269, no. 2, pp. 1425-1431, 1994.

[156] M. Martín-Satué, R. Marrugat, J. A. Cancelas, and J. Blanco, "Enhanced expression of $\alpha(1,3)$-fucosyltransferase genes correlates with E-selectin-mediated adhesion and metastatic potential of human lung adenocarcinoma cells," Cancer Research, vol. 58, no. 7, pp. 1544-1550, 1998.

[157] W. Seo and H. J. Ziltener, "CD43 processing and nuclear translocation of CD43 cytoplasmic tail are required for cell homeostasis," Blood, vol. 114, no. 17, pp. 3567-3577, 2009.

[158] C. X. Andersson, J. Fernandez-Rodriguez, S. Laos et al., "CD43 has a functional NLS, interacts with $\beta$-catenin, and affects gene expression," Biochemical and Biophysical Research Communications, vol. 316, no. 1, pp. 12-17, 2004.

[159] P. Tassone, H. Bond, P. Bonelli et al., "UN1, a murine monoclonal antibody recognizing a novel human thymic antigen," Tissue Antigens, vol. 44, no. 2, pp. 73-82, 1994.

[160] L. Cecco, H. M. Bond, P. Bonelli et al., "Purification and characterization of a human sialoglycoprotein antigen expressed in immature thymocytes and fetal tissues," Tissue Antigens, vol. 51, no. 5, pp. 528-535, 1998.

[161] A. de Laurentiis, M. Caterino, S. Orrù et al., "Partial purification and MALDI-TOF MS analysis of UN1, a tumor antigen membrane glycoprotein," International Journal of Biological Macromolecules, vol. 39, no. 1-3, pp. 122-126, 2006.

[162] K. Okumura, K. Kato, and T. Kobata, "T-cell antigens: section report," in Leukocyte Typing VI: White Cell Differentiation Antigens, T. Kishimoto, H. Kikutani, A. E. G. K. von dem Borne et al., Eds., pp. 23-32, Garland Publishing, 1998.

[163] L. Boumsell, “T-cell antigens: section report," in Leukocyte Typing V: White Cell Differentiation Antigens, S. F. Schlossman, L. Boumsell, W. Gilks et al., Eds., pp. 241-279, Oxford University Press, New York, NY, USA, 1995.

[164] P. Tassone, F. Tuccillo, P. Bonelli et al., "Fetal ontogeny and tumor expression of the early thymic antigen UN1," International Journal of Oncology, vol. 20, no. 4, pp. 707-711, 2002.

[165] P. Tassone, P. Bonelli, F. Tuccillo et al., "Differential expression of UN1, early thymocyte-associated sialoglycoprotein, in breast normal tissue, benign disease and carcinomas," Anticancer Research, vol. 22, no. 4, pp. 2333-2340, 2002. 


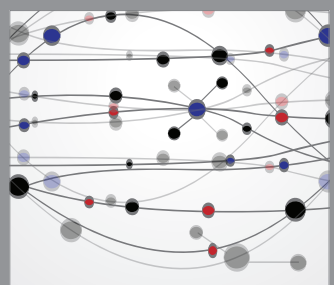

The Scientific World Journal
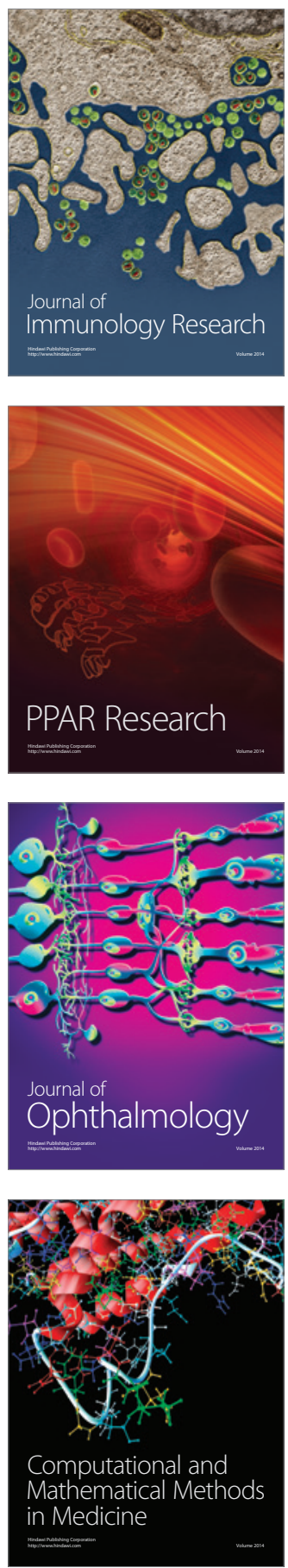

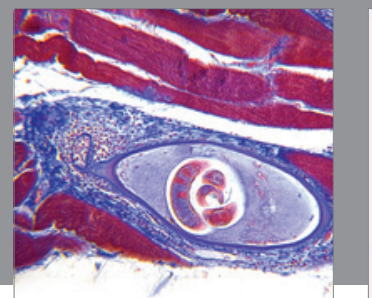

Gastroenterology

Research and Practice
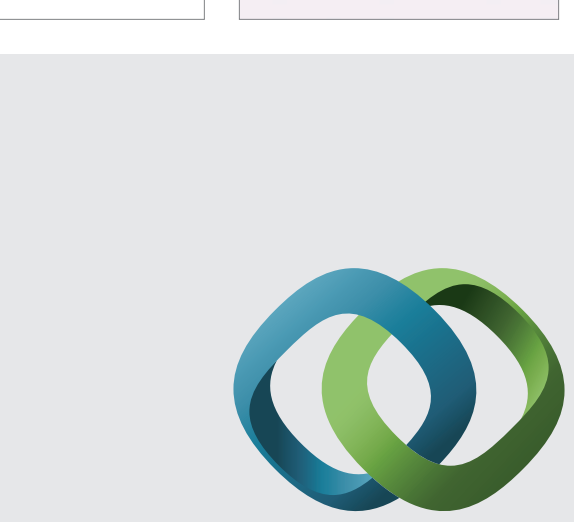

\section{Hindawi}

Submit your manuscripts at

http://www.hindawi.com
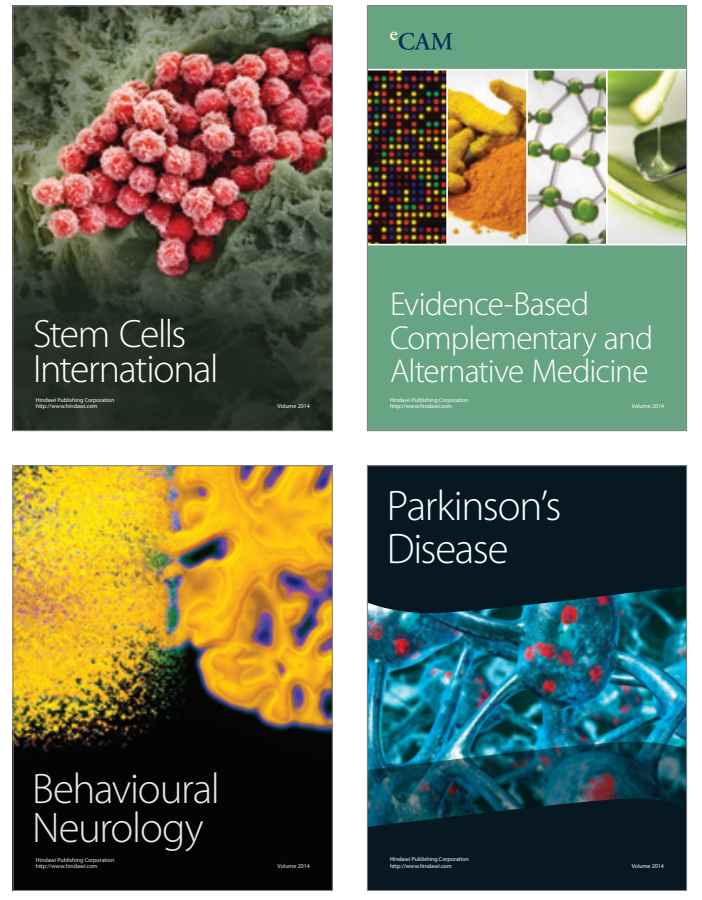
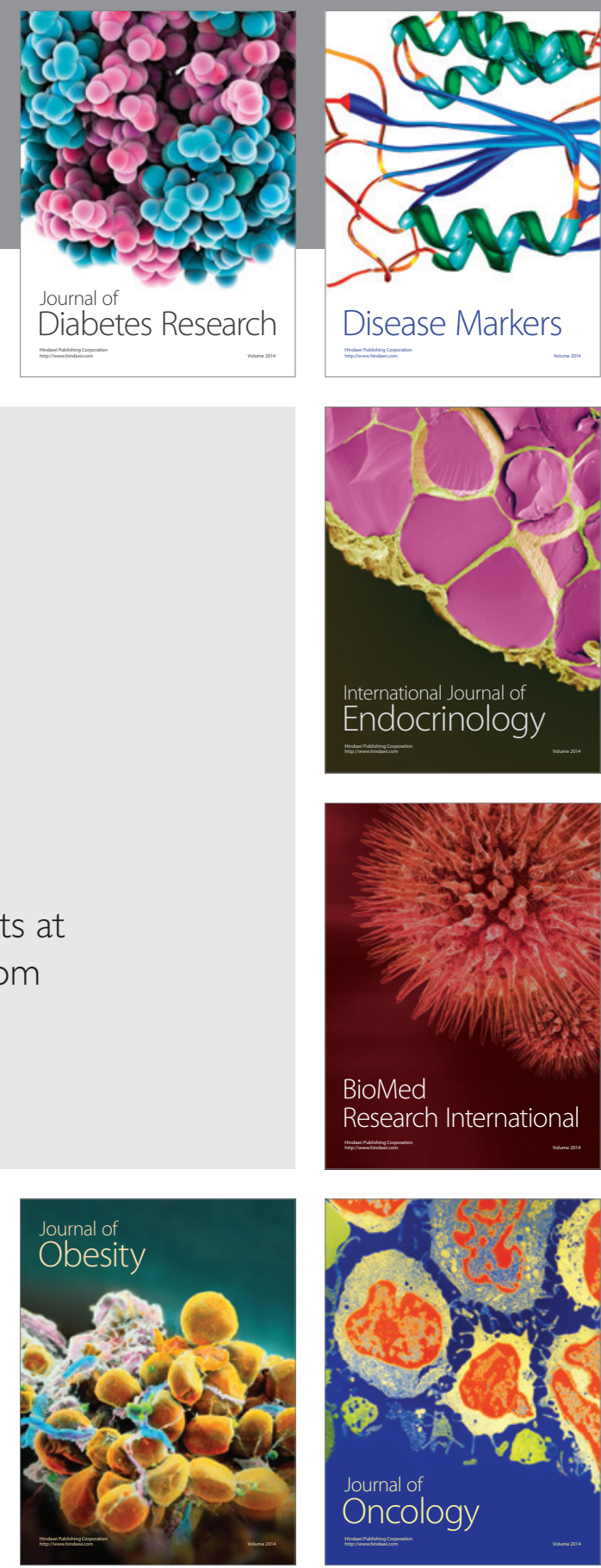

Disease Markers
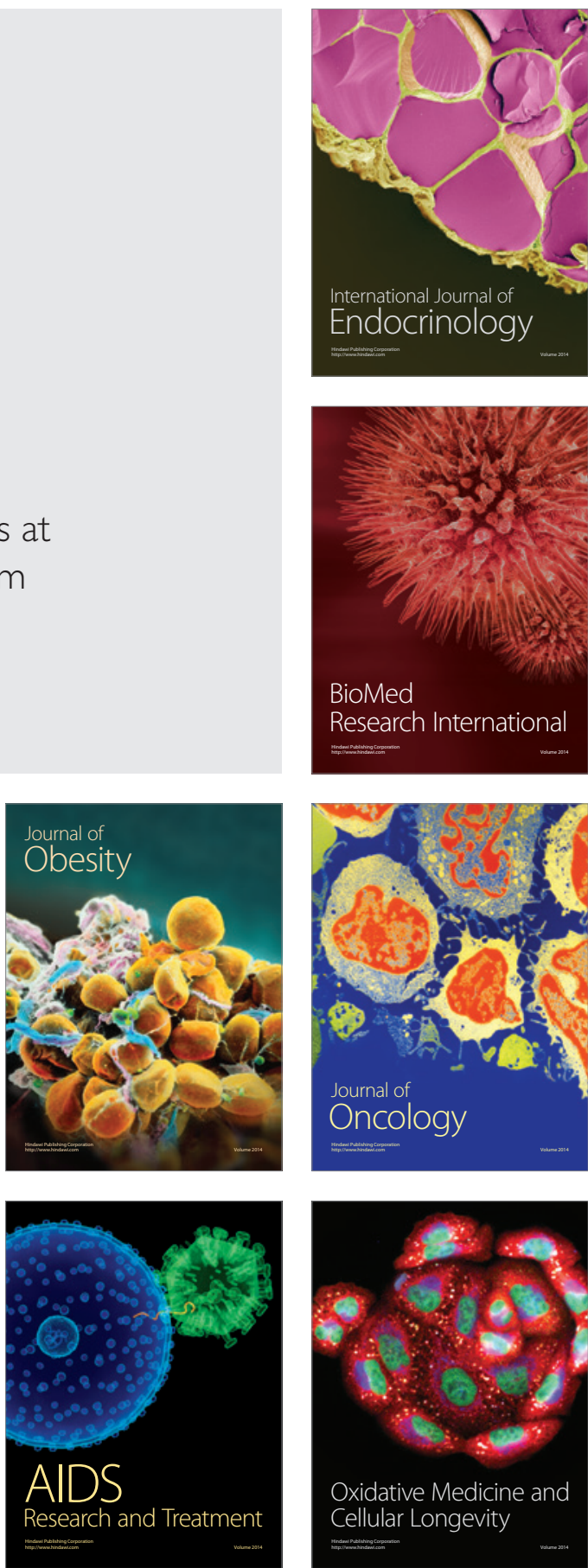